\title{
Rejecting the Conflict Narrative: American Jewish and Muslim Views on Science and Religion
}

\author{
Brandon Vaidyanathan \\ University of Notre Dame, USA
}

David R. Johnson

University of Nevada Reno College of Education, USA

Pamela Prickett

Rice University Department of Sociology, USA

Elaine Howard Ecklund

Rice University Department of Sociology, USA

\begin{abstract}
Sociological research on the American population's views of science and religion has recently burgeoned, but focuses primarily on Christian fundamentalists and evangelicals. Our study advances understandings of how Americans of non-Christian faiths, namely Judaism and Islam, perceive the relationship between science and religion. We draw on in-depth interviews $(\mathrm{N}=92)$ conducted in Orthodox Jewish, Reform Jewish, and Sunni Muslim congregations in two major cities to elucidate how respondents' respective traditions help them frame the relationship between science and religion. Findings demonstrate that members of these religious communities distance themselves from the pervasive conflict narrative. They rely on religious texts and historical traditions to instead articulate relationships of compatibility and independence between science and religion, while developing strategies to negotiate conflict around delimited issues.
\end{abstract}

Elaine Howard Ecklund 1 
Findings push the social scientific study of religion and science beyond a specifically Christian and conflict-oriented focus.

\section{Keywords}

science; conflict; Islam; Judaism; United States

\section{Résumé}

La recherche sociologique sur les opinions de la population américaine sur la relation sciencereligion a récemment bourgeonné : cependant, elle se concentre principalement sur des fondamentalistes et évangéliques chrétiens. Notre étude avance la compréhension de la façon dont les Américains de deux confessions non-chrétiennes, le judaïsme et l'islam, perçoivent la relation entre la science et la religion. Nous nous appuyons sur des entrevues en profondeur $(\mathrm{N}=$ 92) menées dans les communautés orthodoxe juive, la réforme juive, et les congrégations musulmanes sunnites dans deux grandes villes pour élucider comment les traditions respectives des répondants les aident à encadrer la relation science-religion. Les résultats démontrent que les membres de ces communautés religieuses se distancent du narratif du conflit généralisé. Par contre, ils comptent sur les textes religieux et des traditions historiques afin d'articuler la compatibilité et l'indépendance entre la science et la religion, tout en développant des stratégies

pour négocier des conflits autour des enjeux délimités. Les résultats poussent l'étude scientifique sociale de la religion et de la science au-delà de l'accent chrétien orienté envers les conflits.

\section{Mots-clés}

Science; conflit; Islam; Jadaïsme; États-Unis 


\section{INTRODUCTION}

A growing body of historical and sociological research is beginning to challenge the centuries-old narrative that science and religion are in conflict. As Evans and Evans (2008) note, social and life sciences present sets of truth claims about the world thought to be in direct opposition to religious claims about creation and death. Yet conflict is hardly the only logical possibility in the science-religion relationship. Paleontologist Stephen Jay Gould (1997), for instance, famously argued that science and religion should be seen as 'nonoverlapping magisteria': they are domains of autonomous authority_ one dealing with truth and the other with meaning — whose jurisdictions should not overlap. Recent empirical research on American scientists as well as that among college students provides evidence not only for this independence perspective, but also the view that, under certain conditions, science and religion can be compatible (Ecklund, 2010; Scheitle, 2011).

Even among conservative Christians there is no general conflict between science and religion; rather, epistemological conflict is more narrowly restricted to areas such as evolutionary biology and cosmology, while other conflict can be attributed more to factors such as identity (Evans, 2011). This mode of moral, rather than epistemological, conflict stems from conservative Christians' common perception that Darwinists have an anti-religious agenda and that evolution undermines the need for personal responsibility (Noll, 2002).

While we now have a wealth of information on Christians' views on science and religion, we know little about the perspectives of members of other religious groups, including the two largest non-Christian faiths in the US, Islam and Judaism (Pew Research Center, 2015). Despite their growth over recent decades and expected continued growth as well as the overrepresentation of Jews in science in the US (Ecklund, 2010), Jewish and Muslim Americans 
remain underrepresented in survey research. We know little about their orientations to sciencerelated issues, such as evolution, stem cell research, and human reproductive technologies, and are left without a detailed understanding of whether these diverse groups perceive their faith as in conflict with science. The gap extends beyond the US and presents a problem for scholars interested in understanding the connections between religion and science elsewhere in the world. This paper seeks to advance discussion in the social sciences on how non-Christian believers in the US view the relationship between science and religion, starting with Muslim and Jewish Americans.

\section{MUSLIM AND JEWISH VIEWS ON SCIENCE AND RELIGION}

Islam and science have a long and complicated history, with this history a recurrent theme in contemporary discussions. Considerable research has shed light on the flourishing pursuit of science in the early centuries of Islam (Lapidus, 2014; Sabra, 1987). Vital early contributions to astronomy, algebra, geometry, and medicine during this period are credited to prominent Islamic scholars such as Al-Khwarizmi, Al-Kindi, Omar Khayyam, and Ibn al-Nafis. In many of these contributions specific rituals and practices within Islam spurred scientific development, particularly in astronomy. For example, medieval Islamic scholars sought ways to make more precise the calculated times for the required five daily prayers, with mosques employing astronomers as official timekeepers to help believers know exactly when to pray (Masood, 2009). But scientific development in Muslim majority societies slowed after the $16^{\text {th }}$ century. The reasons for this decline continue to be debated, with scholars pointing to the rise of anti-rationalist clerics, external invasions by the Crusaders and Mongols, and a growing dependence on the European world all offered as possible explanations (Ofek, 2011; Saliba, 2007). 
In light of the increasing political and social importance of Islam, the world's fastest growing religious tradition (Pew Research Center, 2015), an emergent body of research has begun to examine contemporary Muslims' views on science. This research identifies a growing debate over evolution in Muslim-majority countries, in spite of a general pro-science and protechnology orientation (Hameed, 2008; Yalçinkaya, 2011). While Muslims accept evolution in general, human evolution represents a point of specific contention (Everhart and Hameed, 2013). Indeed significant proportions of the population in countries like Turkey, Indonesia, Pakistan, Malaysia, and Egypt reject evolution (Hameed, 2008). The hermeneutics of proponents of Islamic creationism, such as Harun Yahya in Turkey, are heavily influenced by American creationists and Intelligent Design advocates. Another influential trend is seen in claims that the Qur'an anticipates a number of scientific theories and discoveries, even the scientific method itself (El-Naggar, 2004, 2005).

While international research on Islam and science is growing, little attention has been paid to American Muslims' views on science. Cimino's (2014) study of Muslims, Hindus, and Sikhs working in engineering and IT occupations in the US provides an important exception. His research finds that applied science professionals who practice Islam blend rational inquiry and personal spiritual growth to construct their own Islamic identities that de-emphasize criticisms of secular values like science. Perceiving applied science as flexible and faith-friendly and natural science as critical of religion, Muslim applied science professionals' occupational backgrounds shelter them from anti-religious ideologies (Cimino, 2014).

In contrast to the relationship of early Islam and science, which seems one of symbiosis and possible synergy (i.e. Islam promotes science, and science encourages deeper piety), ancient and early modern Jewish thinkers sought to separate science from theology. This separation was 
maintained by theories of natural philosophy whereby 'Jewish faith was safeguarded from science and science was protected from the unwarranted intrusions of Jewish faith' (Ruderman, 1995: 82). Influential medieval Jewish philosopher and physician Maimonides maintained that there could be no contradiction between God's truths and scientific findings because humans have a limited capacity to know anything with certainty. Maimonides believed, according to Efron (2007: 92), 'When there seemed to be a conflict, it owed to our imperfect grasp either on God or on God's work, or both'. Efron (2007) argues that this perspective remains influential among contemporary observant Jews drawn to science. Others sometimes refer to the work of Nahmanides (1194-1270), who accepted science but devalued it as compared to the divine security of Jewish thought (Langermann, 1992). Nahmanides' views contributed to a long history of Jewish thought in which scientific knowledge was deemed valid but not as valuable as religion (e.g. the Torah) (Langermann, 1992).

Research on contemporary Jewish approaches to the science-religion relationship is also scarce. This may be in part because there is little public controversy between Judaism and science issues. Indeed, Jewish intellectuals in the mid- $20^{\text {th }}$ century played a prominent role in shaping the secular liberal cosmopolitanism that is taken for granted in academia, and did so through a protracted struggle against Christian and anti-Semitic biases that had historically excluded them (Hollinger 1998). Data also suggest that community context—including the degree of religiosity or secularity — has little effect on Jewish identity (Hartman and Sheskin, 2013). Further, when it comes to reproductive technologies such as human embryonic stem cell research and in-vitro fertilization (IVF), which are disputed among many Christians, there is relatively little debate in Jewish ethics. Prainsack (2006) argues that Jewish ethicists tend to interpret non-prohibited actions as justifiable and are favorably disposed to technologies that 
foster the creation of life. Research also finds American Jews to be overrepresented in scientific professions (Ecklund and Scheitle, 2007; Ecklund, 2010), which could mean that there is little basis for tension with science in this religious tradition. Yet, there is no published research on the American Jewish population's actual views on science issues.

The gap in understanding of how US Muslims and Jews understand the relationship between faith and science is particularly noteworthy because of the significance of these traditions to world history and to US religious culture. This article offers a systematic examination of how leaders and members in Jewish and Muslim congregations understand this relationship. Drawing on data from in-depth interviews in two major metropolitan centers in the Midwest and Southwest, we examine how Jewish and Muslim Americans view the relationship between science and religion. To what extent do they see science and religion as in conflict? What other frames might they employ to make sense of the relationship? How do their views compare to the perspectives found in the dominant literature, including that on conservative Christianity? We see the following as an important step in advancing a dialogue for further research on what the perspectives of believers of these traditions contribute to understandings of the science-religion relationship.

\section{DATA AND METHOD}

We draw on data from in-depth interviews $(\mathrm{N}=92)$ conducted in two major metropolitan centers of the Midwest and Southwest between 2011-2013. Twenty-three congregations from Christian, Muslim, and Jewish religious traditions were selected to participate in a broader study that examines the way members from a variety of religious traditions view the science-faith interface. The sub-sample examined in this paper comprises three Reform Jewish synagogues $(\mathrm{N}=40)$, two Orthodox Jewish synagogues $(\mathrm{N}=24)$, and three Sunni Muslim communities 
( $\mathrm{N}=28$ ). While 'Jewish' may refer to both religious and ethnic identity, by sampling within synagogues we have sought the perspectives of practicing religious Jews. Most Muslims in the US are Sunni, with South Asians and Arabs among the two largest ethnic groups (Schmidt, 2004). The sample in this study is comprised of 26 South Asian and 2 Arab Muslims. Most mosques in the US are segregated by race/ethnicity, and because they fare better than average on income and education, South Asian Muslims have established their own mosques and associations in greater numbers than other ethnic subgroups (Serhan 2015). Our sampling strategy did not permit inclusion of Shiite Muslims, who represent 11 percent of American Muslims (Pew Research Center, 2015).

Of the Jewish study participants, 95 percent have bachelor's degrees, 45 percent are female, and ages ranged from 23 to 78 years old. With respect to the Muslim study participants, 43 percent have bachelor's degrees, 45 percent are female, and ages ranged from 18 to 63 years old. Later we note the occupational background of participants as they are quoted, including the majors of enrolled university students working towards a degree.

With the permission of congregation leaders, researchers conducted participant observation at various events and recruited potential respondents for interviews in order to create a diverse sample across age, gender, and socioeconomic status. Some were directly approached by researchers; others were recommended by congregation leaders; and still others were recruited through different snowball sampling chains to maximize variation. Respondents participated in semi-structured interviews that focused on their views of science and various science-related issues. The average interview lasted 66 minutes. The interview guide was comprised of six sections: Religious Beliefs and Practices; Experiences with Scientists; Thoughts on the Science and Religion Interface; Specific Science Issues; Science in Religious 
Organizations; and Demographics. For the purposes of this article, we focus on questions asked about respondents' general views of the relationship between science and religion: 'Some say there is a conflict between science and religion. How would you personally respond to such a statement? What, if any, are the areas of conflict that you see?' We also asked what their faith traditions taught them about specific science-related issues, including evolution, human embryonic stem cell research, human reproductive genetic technologies, and the environment. Interviews were manually transcribed and subsequently coded for pertinent themes in ATLAS.ti.

Next we identify the diverse ways in which Muslim and Jewish faith communities in the United States might see the relationship between science and religion, examining responses within each religious community we studied. We have divided the analyses by faith—Jewish and Muslim, respectively — in hopes of making the findings more accessible to scholars of each tradition. Despite their differences, we actually find an interesting amount of overlap in the responses of believers of each faith, including a propensity to reject the conflict narrative and to instead see science and religion as either compatible or independent phenomena.

\section{RESULTS}

\section{Reform Jewish perspectives on science and religion}

\section{Separate realms}

The dominant theme among our Reform Jewish respondents is that science and religion do not conflict because they are independent from one another. As one businessman ${ }^{1} \operatorname{articulated}^{\text {: }}$ 'I think that science and religion inhabit two separate spheres of human thought and human activity. There's really very little interface between them'. He elaborated:

Well, they inhabit separate realms. They're not incompatible. If you spend from eight o'clock in the morning to eight o'clock in the evening in your apartment and you leave 
and when you leave three minutes later your roommate comes in and spends from eight o'clock to eight o'clock in the morning in the apartment, are you and your roommate compatible? You never see them...They are not incompatible because they inhabit completely separate realms of thought.... religion and science are both compartmentalizable and compartmentalized.

Note the nuance in his words: he does not say that religion and science are compatible in the sense of informing and influencing one another, but simply that they are not incompatible or conflicting. Others reflected a view close to Gould's (1997) idea of non-overlapping magisteria, emphasizing that religion and science had their respective domains of authority. For instance, one male high-school math teacher ${ }^{2}$ stated: 'There are some things that you have to go with faith and accept it the way it is. And there are some things that you need to have the scientific proof in order for the pop[ulation] — especially if you're taking a vote on something'. Some believed not only that they do not overlap, but that they also should be kept separate. One retired female attorney $^{3}$ put it: 'You know, you can study one and you can study the other [science and religion]. But if you try to reconcile one with the other then they conflict. So I don't try'.

\section{Occasions of conflict}

The pervasive belief among our Reform Jewish respondents is that science and religion come into conflict only when one relies on literalist interpretations of the scriptures. As one female religion teacher expressed it:

In Judaism - conservative, reform, reconstructionist, etc, be as liberal as you want to. Nobody, none of those read the Torah literally. So the world was created in six days? That's ridiculous; there wasn't even a sun and a moon until the third day! ... So how long 
was the first day? What do I care? What that story tells me is there was nothing, and now there's all this, and God did it. So I don't have a conflict between science and religion.

Our Reform Jewish respondents insisted not only that literalism leads to a conflict between science and religion, but also that literalism is bad theology. As one Rabbi ${ }^{4}$ insisted, literalism is itself a recent theological innovation:

[The Torah] was never considered to be a literal document until a few hundred years ago when all of a sudden you had this tremendous division within the Jewish world...This was always a tradition that took that as metaphor and as mythology and as wisdom literature, not as literal scripture. So part of my argument is that the whole science-religion thing is actually a modern division that didn't used to be there....It never was an issue until really...post-Enlightenment, when people's foundations started to get shaken a little bit. This type of view could help explain why there are more Jewish scientists than evangelical ones. Whereas evangelicals may avoid studying evolutionary biology for fear of conflict with biblical interpretations (Evans, 2011), there appears to be little epistemological concern or perceived moral conflict between science and religion among Jewish respondents that would provoke hesitation to enter a science profession.

Because the scriptures are not meant to be interpreted literally, they are not to be seen as a source of scientific explanation. As one respondent, a female law professor' said: 'I don't think of [the Torah] as an actual explanation of the origins of the earth. I think of it as this beautiful text, a beautiful story, allegories, things that have important lessons, but not actually an explanation of any kind of natural phenomenon'. Similarly, a Rabbi ${ }^{6}$ said, 'There's lots of great stuff in it, but it's not a science book. Doesn't mean it's less valuable, it doesn't mean it's less true...That's not what its function is'.

Elaine Howard Ecklund 11 
Distancing themselves from literalism also was a mode of boundary-work, by which they asserted their identities as Reform Jews and distanced themselves from Orthodox Jews and from Christians. As one female computer programmer" said: 'The way I look at the Torah is not as an historical document. And this is why I'm not Orthodox [laughs]'. Another woman, an assistant $\mathrm{Rabbi}^{8}{ }^{8}$ distancing herself from scriptural literalists, said, 'I think there is an understanding though that as liberal Jews we also need to not have such a narrow world view'. Another female volunteer ${ }^{9}$ quoted a Rabbi who told her, 'The only people who believe the literal word of the Torah are Christians. But Jews follow rabbinic law'.

In occasions of clear conflict, science wins

While generally rejecting the view that science and religion are in conflict, our Reform Jewish respondents acknowledge that there are instances when scientific theories and discoveries appear to contradict scripture, such as in stories of miracles. In such cases, in contrast to what we will see among Orthodox Jewish respondents, Reform Jews saw scientific explanations as superseding religious ones.

But privileging scientific explanations does not invalidate scripture. On the contrary, as some respondents insist, it makes scripture even more reliable. For instance, one female medical internist ${ }^{10}$ told us: 'in my mind, by being able to provide a scientific explanation for some of the miracles, quote unquote, that are in the Bible, it makes the Bible more believable to me'. In these ways, Reform Jewish respondents maintain a relationship of independence between science and scripture that allows them to value both in different ways. 


\section{Orthodox Jewish perspectives on science and religion}

\section{Compatible realms}

In comparison to Reform Jewish respondents who saw science and religion as separate spheres, Orthodox Jewish respondents tended to see science and religion overall as compatible. This was true whether they identified as conservative or liberal. One respondent, a female retired teacher, ${ }^{11}$ said: 'I do believe there is a blend. It's not a big, fat wall separating the two. I don't feel that at all. I embrace both because I feel there is a blend'. Similarly, a male finance professional $^{12}$ claimed: 'I don't see [conflict] at all... as time goes on, you generally find that science tends to validate a lot of our religious beliefs'.

While Reform Jewish respondents talked about how the believability of religious claims depended on their compatibility with scientific explanation, Orthodox Jewish respondents talked about how religion, by answering questions of meaning, makes science itself worthwhile. As one female healthcare professional ${ }^{13}$ stated:

Science...It feels limitless, what we can do. And religion...is just answering that question of why...[I]f there is no God, then it's almost like there's no point... So if everything stops existing at one point, then there's no point in even trying to understand everything....So the religious part, for me, is making the science something that means something.

One Rabbi in the conservative synagogue ${ }^{14}$ admitted that there are some 'strict interpreters' of scriptures who see science and the Bible as contradictory, but he himself thought otherwise. 'There are many very Orthodox writers, thinkers, scientists who feel that they can reconcile the two... One of the leading books on the Big Bang theory is written by a very Orthodox physicist who I happen to know very well, and so I'm not interested in saying that 
science is wrong'. Similarly, a female manager from the more liberal synagogue insisted that the Jewish faith itself can motivate scientific inquiry:

I would say that God is the ultimate scientist...I believe that we have a religious obligation to study science and to know as much as we can scientifically....And very specifically, I can to speak to Orthodox Judaism. We have an obligation...to learn everything we can about this world because I believe this is all part of Tikkun Olam [repairing the world]. I refuse to accept the view of many of our community holds - I don't want to blast any specific Orthodox Jewish movement, but there are many in the community ... who believe that studying science is an abasement, it's an affront to God.

\section{Occasions of conflict}

While generally rejecting the notion of conflict between science and religion, most Orthodox Jewish respondents admitted that there were delimited areas of conflict, particularly around the origins of human life and the age of the universe. One female consultant ${ }^{15}$ from the more traditional Orthodox synagogue, who also initially claimed that science and religion were compatible, told us matter-of-factly: 'We don't validate evolution. God created people, and people did not evolve over time. You know, we believe in the story of Adam and Eve, so that's it'. The retired teacher, quoted above, similarly said of evolution: 'That's a big no-no for us...[T]hat's a direct conflict between creating Adam from dust and then Eve from the rib. So you have that versus the monkey theory', and she preferred to believe the Bible.

In order to overcome perceived conflicts in these delimited areas, some respondents appealed to scholars in the Jewish historical tradition whose commentaries they saw as supporting modern scientific views. For instance, one male banker said: 
[L]ook at the writings of Nachmanides... when Nachmanides wrote about the story of Genesis - you know — the description about how God created the world—you know—it's very similar to the Big Bang theory. And a lot of what he wrote about-you knowmatches very similarly to like modern string theory. If you're reading like his description of the creation of the world versus today's description, the two are very similar.

An oil company executive ${ }^{16}$ from the same synagogue declared: ' $I$ believe in a theistic evolution'. Referring to another rabbinical scholar, he added: 'In terms of the creation of the world, there have been plenty of commentators... who have clearly stated that things as they are presented in, let's say the first two chapters of Genesis, are not to be taken literally', referring to Maimonides in particular. Another respondent from the conservative synagogue, a geology student, ${ }^{17}$ claimed that scripture even has support for the existence of dinosaurs. Leafing through the pages of the Torah, he explained to the interviewer:

[W]]hat's really interesting on the fifth day, which I personally think was the Paleozoic and Mesozoic Era, is the use of this word combination taninim gedolim. Now it translates it here as sea giants. Another way to translate it is as giant lizards or giant reptiles.... So depending on how you translate it, the Torah does mention dinosaurs.

The physicist Gerald Schroeder, who a number of Orthodox Jewish respondents mentioned in our interviews, claims that the Torah hints at the existence of dinosaurs (1997). But other respondents were either unaware of or uncomfortable with this approach, such as the following Rabbi and school principa ${ }^{18}$ who encouraged students to distinguish between facts and scientific claims:

[I]t's an issue where teachers will come to me and say, 'What about dinosaurs?' you know?... And the way that I dealt with it as a Rabbi and an educational leader here is, I 
say, 'You could say, 'Science says the world is 50 billion years old. Science says that there were dinosaurs'. You're not saying it's a fact; scientists say this....Just say that it's science that says it and that science is itself complicated.

Another strategy to overcome conflict is to see science itself as always changing and subject to revision. A female programmer ${ }^{19}$ from a more liberal synagogue said: 'Science goes according to what we currently know and what people have extrapolated from that. But that doesn't mean that all the information is in' - suggesting that future scientific research could corroborate religious claims. A female librarian ${ }^{20}$ from the same synagogue similarly said: 'those [scientific] theories will always change'. Additionally, she thought that matters such as human evolution were irrelevant to how she lived out her faith on a daily basis. '[I]f I believe in evolution, so there is no Adam and Eve? I don't know. I just figure, I got to worry about what I do day to day...And whether that happened literally or didn't happen literally does not affect how I behave'. This serves as another strategy to overcome conflict - to ignore areas of conflict that Jews believe are practically irrelevant to daily life.

Still others did not quite know how to reconcile the two; they admitted they did not completely understand. But they were okay with not understanding, and did not see this as a problem. As one female schoolteacher ${ }^{21}$ said: 'I don't feel there's a conflict. I might not know the answers, but I still believe...there is a connection. I mean, I drive my car and I don't understand how it works, but it works for me [laughs]'. Another female schoolteacher at the same synagogue ${ }^{22}$ similarly said:

I'm sometimes fine with the fact that it's not up to me to be able to understand everything... So there are certain aspects [of the Torah] that are not explainable in a clearcut way. Like, is it really seven days that he created the world...Maybe a day wasn't 
twenty-four hours then. Maybe a day was-you know—-seven thousand years, and then the next day was, 'Okay, let me get it down to a twenty-four-hour period'. So things are not necessarily explained, and I'm sometimes fine with that.

Another strategy to overcome conflict is to appeal to interpretive flexibility. Here, some Orthodox Jewish respondents claimed that Judaism is better able to reconcile science and religion than Christianity is. Just as Reform Jews distinguish themselves from Orthodox Jews, the latter use literalism as a boundary-object to distinguish themselves from Christians. As the geology student ${ }^{23}$ quoted above said:

[W] hen you get to the core of science and religion, there really isn't much of a conflict. However, it does depend on what religion... Christianity is basically a cheap knockoff of Judaism.... The vast majority of Christian philosophy is on taking what it says literally...[T]he Torah has flexibility on a lot of different things to be able to say find leniencies for certain things under certain circumstances and to accept different interpretations of how the world works. There have been many different books published on how to corroborate the Torah and science, and because the Torah has that flexibility...science can therefore be a valid interpretation of how the world functions and how the world was created. Christianity... because you have to take it literally, you don't have that flexibility. That makes it much harder to corroborate the two.

At the same time, Orthodox Jewish respondents were much more reticent than Reform Jews were to interpret scripture as merely symbolic. This became clear when we asked them about how they viewed the miracles mentioned in the Torah, which many of the Orthodox respondents did not believe needed to be scientifically explainable. At the same time, they did not think miracles necessarily defied scientific explanation, with several pointing to the parting 
of the Red Sea as an example in which God could have 'used nature', e.g. a tsunami, to bring about a miracle.

In occasions of clear conflict, religion wins

While Orthodox Jewish respondents overall maintained that science and religion were compatible, they admitted to the possibility of conflict in delimited cases. And in such instances, they would side with the Bible over science. As one male computer scientist ${ }^{24}$ told us:

[If,] for instance, someone does a study that says keeping kosher means you die earlier or something. So if you said somebody came up with that kind of study, I would say well there's something that may be wrong with that study... The Torah wouldn't tell us to do anything that would be against our health.

As one $\mathrm{Rabbi}^{25}$ articulated the relationship between science and scripture: 'There often are ways to reconcile what seems to be the differences between the two of them'. However, 'if they're really irreconcilable, then we obviously follow our Bible'.

\section{Sunni Muslim perspectives}

Our Sunni Muslim respondents across the three communities we studied rejected the notion that science and religion are in conflict, and largely articulated narratives of compatibility. One female college senior ${ }^{26}$ stated: 'For us, science and religion are not completely separate. Our faith encourages us to ask questions about nature or even the signs of God'. Some, like a male engineering professor ${ }^{27}$ from another community, claimed: 'In reality, science and religion are telling you the same thing'. Occasionally, we heard narratives of independence. One male attorney, ${ }^{28}$ for instance, stated: 'They're totally separate things... Science is concerned with understanding the natural world. Islam is concerned with understanding the spiritual reality'. But 
the dominant approach in the communities we studied was that science and religion are complementary.

\section{Religion encourages science}

A prominent theme among Muslim respondents, which emerged much more frequently than it did among Orthodox Jewish respondents, was that their faith encouraged and motivated scientific inquiry. As one male dentist ${ }^{29}$ said:

[T] o me there is not a conflict because I believe that human beings are trying to understand laws that God has put on Earth. For example, gravity is a phenomenon that God has - we have to discover it through science and hard work. So once we understand gravity, we can do certain things that we couldn't do if we didn't understand it.

Similarly, the female student quoted above said that 'even if it's only on an academic level, like on a completely secular level, if you're researching something, even that comes back around to help you reflect. That's one of the things that the Qur'an says, actually encourages'.

Muslim respondents thus argued that learning about the world through science was a means of knowing God better. As a male biochemistry student ${ }^{30}$ put it: 'I'm a science student, I'm majoring in biochemistry. Everything I learn in class, all that does is strengthen my affirmation that God exists'. Like some of our Orthodox Jewish respondents, he believes that 'God wants us to go out and test things and find out about the world around us'. One female premed student ${ }^{31}$ talked about how scientific inquiry is a means of proving that the Qur'an is true: Actually, the Qur'an says itself that science is supposed to be the proof of Qur'an. God says, 'No, look at science. Go discover and see for yourself that this is the truth. Go bring your evidence against it so we can show you this is the truth'. So it's supposed to be a support of it. It's supposed to show you that God created everything... 
Another respondent, a male engineering student, talked about how scientific inquiry would lead a Muslim scientist to draw closer to God:

[E]very concept that he would learn or discover, he would say subhanahu wa ta'ala you know how, glory to Allah, subhanahu wa ta'ala. He would, he would recognize that all these things that he's discovering and all this knowledge that he is exploring, he takes it back to Allah...this is from the creator.

\section{Science confirms and validates scriptures}

A recurring theme among our Muslim respondents was that science validates what is already in the scriptures. Many insisted that the Qur'an, while not being a scientific text, contains descriptions of scientific truths that we are only now discovering. As the male dentist ${ }^{32}$ quoted above stated:

We believe that some of the miracles that the Qur'an has described, scientific miracles, have already been discovered. The Qur'an talks about salt and fresh water-there's a barrier in between. And that was recently discovered maybe in the last 50 years...The Qur'an is not a scientific book per se, but it does refer to different scientific phenomenon that have already been discovered, and they turned out to be true.

Another respondent, a female pharmacy technician, ${ }^{33}$ similarly argued that the Qur'an described the stages of pregnancy accurately, long before science understood fetal development. Thus, she argued, 'Whatever science will discover, that religion will have that, and the Book has it'. The male engineering student expressed a similar sentiment, arguing that science 'is living up to the Qur'an, not the other way around...I take Qur'an as the essential, as what's the foundation, and science is trying to live up to that, trying to discover.' 
Some respondents drew on this Islamic motivation for science to draw a boundary between themselves and Christians. They claimed that Islam offered greater compatibility with science, and that conflict between science and religion was restricted to western Christianity. As the engineering professor said:

Unfortunately, what I see is that the conflict between Christianity and religion had been universalized as the conflict between science and religion.... In Islam, when we hear about science and conflict between religion, I say, 'What religion?' Because in my religion, I don't see a conflict between science and religion.... What may cause a conflict in Christianity and science may not be valid for Islam and science.

Another respondent, a university dean, ${ }^{34}$ similarly argued, 'Christians are far more dogmatic about not believing in science than Muslims are...The kind of disdain for science that I find amongst a lot of Christians'. But here he interrupted himself, realizing: 'But then there are some worrying signs amongst Muslims that there is literalist movement'. Concerns about such literalism emerged in interviews with many of our respondents, even from the same community as this respondent.

\section{Occasions of conflict}

Though insisting on the complementarity of science and the Qur'an, respondents admitted that human evolution was sometimes an area of conflict. Most respondents claimed they had no problem with evolution in general, but did have problems specifically with human evolution. As a female pre-med student ${ }^{35}$ said:

The only thing that I think is a major discrepancy is evolution. We believe in evolution, but we don't believe we came from one organism. We don't believe in the fact that we 
came from monkeys or anything of that sort and, as of right now, there's no evidence that they clearly — that we did come from monkeys.

This respondent claimed that 'unless you can show me there's an actual transition', she didn't see scientific evidence for human evolution from other species as convincing. Yet, she claimed that Islam itself taught evolution: 'Actually, one of the names of our God is Al Bari, which means 'the evolver', so it talks about it in the Qur'an, how God can change us over time and how he does change creations over time, and how, within a generation, things can change'. Another respondent, a female healthcare professional, ${ }^{36}$ similarly distinguished general evolution from human evolution: 'I feel like humans have evolved in size but not cross-species.... So I don't believe that once upon a time, we were orangutans or monkeys and then through whatever natural selection and environment pressures, we evolved into human beings'.

But not everyone, even from the same community, shared this view. Some were more agnostic about how literally to interpret scriptures about human creation. A religion professor, ${ }^{37}$ for example, insisted on the interpretive flexibility of the Qur'an, which could overcome areas of apparent conflict:

Qur'an was not a written text... It was an inspired speech, okay? So... because of that, that inspired nature of the text, it's really not very detailed and very firm, you know, as a prose will be....Qur'an is open to many interpretations. So if you feel that obviously there is a conflict we immediately interpret the text and we say that we will not take it literally so that also eliminates the conflict between the two.

Nevertheless, when probed on the specific question of evolution, he shared the view that 'humans did not evolve but they are created as human'. Some others rejected evolution because 
it obviated the need for God in explaining creation. As the male engineering professor ${ }^{38}$ quoted earlier said:

I don't think that evolution is the answer, because I'm an engineer and from an engineering point of view, there has to be a plan, a design. Without design, things cannot evolve or function... Who is the designer? Who wrote the code for things, how they will behave? So, I understand sure, that evolution will work with enough framework, but our data set is very small. Two hundred years of out like millions and billions of years.

Another respondent, a male attorney, ${ }^{39}$ similarly argued that the naturalistic account of human evolution was simply inadequate because it leaves out the human soul, which is beyond the scope of science:

If we're talking about the theory that life has evolved from simple to complex, okay. But I don't necessarily believe that humans came from single cells. This theory is okay when it's describing how most things came to be, but for humans it leaves out the soul and the spirit. Science can't explain that; it's hard to reconcile. Evolution can probably explain most things, but for humans and the spirit it just falls short.

Still others, like the following female nurse, saw evolution as problematic because it contested God's active agency. 'I don't think it can be compatible with the teachings of the Qur'an. I think ... Almighty is the one in the control here'.

In occasions of clear conflict, religion wins

Thus, while arguing that overall science and religion are complementary of one another our Sunni Muslim respondents also admitted that there were clear areas of conflict. In such cases, as the female pharmacy technician ${ }^{40}$ quoted above said, 'I think that religion and science can go together, but at the end religion wins'. Most of the respondents did not believe that 
science refutes religion so much as needed to catch up with it. The female pre-med student ${ }^{41}$ said:

For example, like angels and jinn [a spiritual entity in Islam] and life after death, these are things that kind of counteract science. There's no proof of it, there's no evidence, but I believe in those things. And if you're just a hard-core scientist with no religious beliefs, you'd probably think it's crazy to believe in things like that. And I see where some people might think there is discrepancies there, or there is a conflict between science and religion, but in my head, it's more like it just hasn't been proven yet.

One female college senior ${ }^{42}$ stated that if scientific research posed a challenge to her faith, then ' $I$ kind of see it as a limitation of our understanding. Because I feel like science - our understanding is constantly changing. It's constantly evolving. It's constantly growing'. Because of the changing nature of science, for these respondents the safer course was to confidently stick to religious belief.

\section{DISCUSSION AND CONCLUSION}

Our interviews revealed a number of similarities and differences in views on the sciencereligion relationship among Reform Jews, Orthodox Jews, and Sunni Muslims. Rather than generalizing to all Muslims or Jews, our focus is instead on how members in these congregations maintain their different views of the science-religion relationship, and what strategies they adopt to reject the conflict narrative.

Respondents engaged religious texts and traditions to develop frames to reconcile potential areas of conflict, in effect discounting the belief that science and religion are inherently in conflict. This was captured best when one of our Orthodox Jewish respondents, a male computer scientist, said bluntly, 'I don't see any conflict in science and religion'. Instead, the 
conflict was with Christianity, with respondents of both Jewish and Muslims congregations drawing out the compatibility between their own faiths and science. Despite their theological differences, adherents of Judaism and Islam clearly shared an expressed desire to distance themselves from the conflict narrative in this study by distancing themselves from anti-science views they perceived as typical of mainstream conservative Christians.

Of course, there were nuanced distinctions, with our Reform Jewish respondents insisting on an independence of science and religion as separate realms, while our Orthodox Jewish respondents insist on the compatibility of science and religion. The appeal of the independence view among these respondents is understandable in light of the historical origins of American Reform Judaism — particularly, its attempt to embrace modernity and to bring its institutional values in harmony with mainstream societal norms and values (Steinberg, 1965). In seeing science and religion as fundamentally compatible, Orthodox Jewish respondents perceived science as dealing with how the world works and religion as dealing with the 'why' questions, going so far as to suggest religion makes scientific inquiry meaningful and worthwhile in the first place. Some even talked about scripture providing an obligation to study the world scientifically. Our Sunni Muslim respondents see a symbiosis between science and religion. They frequently interpreted scripture as obligating and motivating scientific inquiry, believing also that scientific research can validate the claims of scripture.

Muslims and Jews also relied differently on religious authorities when navigating the science-faith interface. Jewish participants frequently cited their rabbi or historic rabbinical scholars, yet our analysis produced no evidence of Islamic respondents turning to or citing an imam when a science-related issue arose. The view among Muslims that the Qur'an is complementary to and supports science may negate one's need to defer to external religious 
authorities, or at the very least minimize one's reliance on them when potential conflict appears. This may be especially true in the US, where Muslims are better able than in other countries to "shop" for a mosque (and hence imam) that fits individual preferences (Wolfe 2005). In general, the role of non-Christian religious authorities navigating the science faith interface is understudied and may provide important new insights.

Yet both Muslims and Orthodox Jews identify areas of conflict between science and religion, which Reform Jews are able to sidestep by distancing themselves from literalism and interpreting scriptures symbolically. For some of our Jewish respondents (but not for Muslims), the age of the universe is one such area of conflict. But here too, within the same synagogue, we found conflicting opinions. While some claimed, 'I know that Judaism believes the world is approximately 6,000 years old', others argued that numerous commentators have throughout the centuries provided alternative interpretations of scripture that support an old earth. Others, using even literalist readings of scripture, argue that it offers hints about the existence of dinosaurs. Such strategies allow Orthodox Jewish respondents to see science as ultimately validating faith. A more contentious topic is human evolution, which many of our Orthodox Jewish and Sunni Muslim respondents reject as incompatible with their faith traditions. They nevertheless hold to the compatibility of science and religion, by claiming that these issues are not practically relevant to how they live out their faith, or by admitting that they do not know how to resolve the tension but are fine with not knowing. They do not see the tension as weakening or challenging their faith. And still others reassure themselves that science itself is constantly under revision and will eventually reconcile with scripture by developing a more adequate explanation of human origins. Given that Muslims and Jews claim such issues are not practically relevant to their lives, 
case studies in which the moral or practical relevance of the science-faith interface is salient would offer a fruitful avenue for future research.

With respect to the study of science and religion among Muslims, this work builds on the work of Cimino (2014) in two key ways. First, that Muslims (and Jews) distance themselves from Christian notions of religion and science expands Cimino's (2014) argument that other discourses influence Muslim discourse on religion and science. Views of the science-religion relationship are relational-constructed in opposition to the discourses of dominant societal religious traditions. Second, in tension with Cimino's (2014) results, we find that evolution remains a contentious topic for many Muslims working in science-related occupations, even those in medical fields. Disentangling the effects of training in basic and applied science would be an important step to better understanding of how particular career paths influence Muslims views of evolution. Research on Islamic views of the science-faith interface would also benefit from better understanding of the views of non-Sunni Muslims as well as those of other ethnic backgrounds (e.g. Arab, African American, etc.).

Altogether, this study underscores the need for scholars to give greater attention to the variability of perceptions of science among non-Christian faiths. This is critical for those interested in the relationship between science and religion in both the United States and abroad. Indeed, recent research on scientists finds that perceptions of conflict between science and religion are more pronounced in Western regions such as the US, UK, France, and Italy relative to regions such as India, Hong Kong, and Taiwan (Ecklund et al., forthcoming). We hope that our study will generate additional discussion and inquiry among those interested in the relationship between science and religion as well as scholars interested in comparative religion. 
Despite widely circulated claims in the US press about the decline of religious affiliation, elsewhere in the world the importance of religion is rising. The number of Muslims worldwide is projected to nearly equal that of Christians by 2050 (Pew Research Center 2015), suggesting more research is needed on how they make sense of and act in the world, as well as what role religion plays in how they frame their understandings of others. As our data suggest, science is an area where those outside Christian traditions draw out their differences with Christianity. Both our Jewish and Muslims respondents believed that in cases of clear conflict, religion trumps science and as such it is important to give attention to the ways religion will continue to influence how people understand the world around them.

\section{Funding}

Data collection for this paper was funded by the John Templeton Foundation, Religious Understandings of Science Study (Grant \#38817), Elaine Howard Ecklund PI.

\section{Acknowledgements}

The authors thank Max Katner for assistance with coding.

\section{References}

Cimino R (2014) Mystical Science and Practical Religion: Muslim, Hindu, and Sikh Discourse on Science and Technology. Lanham: Lexington Books.

Ecklund E H (2010) Science vs. Religion: What Scientists Really Think. Oxford: Oxford University Press.

Ecklund E H and Scheitle C (2007) Religion among academic scientists: Distinctions, disciplines, and demographics. Social Problems 54: 289-307. 
Ecklund E H, Johnson D, Scheitle C, Matthews K, and Lewis S (forthcoming) Religion among scientists in international context: A study of scientists in eight regions. Socius.

Efron N (2007) Judaism and Science: A Historical Introduction. Westport, CT: Greenwood Press.

El-Naggar Z (2004) Treasures in the Sunnah: A Scientific Approach, Vol. 1. Cairo, Egypt: AlFalah Foundation.

El-Naggar Z. (2005) Treasures in the Sunnah: A Scientific Approach, Vol. 2. Cairo, Egypt: AlFalah Foundation.

Evans J (2011) The growing social and moral conflict between conservative protestantism and science. Journal for the Scientific Study of Religion 52: 368-385.

Evans J and Evans M (2008) Religion and science: beyond the epistemological conflict narrative. Annual Review of Sociology 34: 87-105.

Everhart D and Hameed S (2013) Muslims and evolution: A study of Pakistani physicians in the United States. Evolution: Education and Outreach, 6: 1-8.

Hameed S (2008) Bracing for Islamic creationism. Science, 322: 1637.

Hartman H and Sheskin I (2013) The (dis)similarity of a minority religion to its broader religious context: The case of American Jews. Review of Religious Research 55: 459-490.

Hollinger D (1998) Science, Jews, and Secular Culture: Studies in Mid-Twentieth-Century American Intellectual History. Princeton, NJ: Princeton Univ. Press.

Langermann YT (1992) Acceptance and devaluation: Nahmanides' attitude towards science. Journal of Jewish Thought and Philosophy 1: 223-245.

Lapidus I (2014). A History of Islamic Societies, 3rd ed. New York: Cambridge University Press. Masood E (2009) Science and Islam: A History. London: Icon Books. 
Ofek H (2011) Why the Arabic world turned away from science. The New Atlantis (30): 3-23. Pew Research Center (2015) The Future of World Religions: Population Growth Projections, 2010-2050. http://www.pewforum.org/2015/04/02/religious-projections-2010-2050/

Prainsack B (2006) Negotiating life: The regulation of human cloning and embryonic stem cell research in Israel. Social Studies of Science 36(2): 173-205.

Ruderman D (1995) Jewish Thought and Scientific Discovery in Early Modern Europe. New Haven, CT: Yale University Press.

Sabra A (1996) Situating Arabic science: Locality versus essence. Isis 87: 654-670.

Saliba G (2007) Islamic Science and the Making of the European Renaissance. Cambridge: MIT Press.

Schmidt G (2004) Islam in Urban America: Sunni Muslims in Chicago. Philadelphia: Temple University Press.

Schroeder G (1997) The Science of God: The Convergence of Scientific and Biblical Wisdom. New York: Free Press.

Serhan, R (2014) Muslim immigration to America. In: Haddad Y and Smith J (eds) The Oxford Handbook of American Islam. Oxford: OUP, pp. 29-46.

Steinberg, S (1965) Reform Judaism: The origin and evolution of a 'church movement'. Journal for the Scientific Study of Religion 5: 117-129.

Wolfe, A (2005) The Transformation of American Religion. Chicago: Univ. of Chicago Press..

\section{Author biographies}

Brandon Vaidyanathan is Director of Research for the H.E. Butt Family Foundation in Texas and Public Policy Fellow at the Center for Ethics and Culture at the University of Notre Dame.

Address: 4306 Yoakum Blvd Suite 430, Houston, TX 77006

Email: rvaidyan@alumni.nd.edu

Elaine Howard Ecklund 30 
David R. Johnson is Assistant Professor of Higher Education at the University of Nevada Reno. Address: 1664 N. Virginia St, Reno, NV 89557.

Email: drj@unr.edu

Pamela Prickett is a postdoctoral fellow in the Department of Sociology at Rice University. Address: 6100 Main Street, Houston, TX 77005

Email: prickett@ rice.edu

Elaine Howard Ecklund is the Herbert S. Autrey Chair in Social Sciences and Professor of Sociology at Rice University.

Address: 6100 Main Street, Houston, TX 77005

Email: ehe@rice.edu

${ }^{1}$ SWRJ1_Int5

${ }^{2}$ SWRJ2_Int3

${ }^{3}$ SWRJ1_Int2

${ }^{4}$ SWRJ1_Int10

${ }^{5}$ MWRJ Int18

${ }^{6}$ SWRJ1_Int10

${ }^{7}$ MWOJ_Int4. This respondent is a member of what she calls a 'liberal Orthodox synagogue', and doesn't consider herself Orthodox.

${ }^{8}$ SWRJ1_Int11

${ }^{9}$ SWRJ1_Int3

${ }^{10}$ MWRJ_Int6

${ }^{11}$ SWOJ_Int 12

${ }^{12}$ SWOJ_Int6

${ }^{13}$ SWOJ_Int3

${ }^{14}$ SWOJ_Int 1

${ }^{15}$ SWOJ_Int 10

${ }^{16}$ SWOJ_Int12

${ }^{17}$ SWOJ_Int9

${ }^{18}$ SWOJ Int2

${ }^{19}$ MWOJ Int3

${ }^{20}$ MWOJ_Int5

${ }^{21}$ SWOJ_5

${ }^{22}$ SWOJ_Int11 

${ }^{23}$ SWOJ_Int9
${ }^{24}$ SWOJ_Int8
${ }^{25}$ SWOJ_Int1
${ }^{26}$ SWM1_Int15
${ }^{27}$ MWM_Int4
${ }^{28}$ SWM1_Int17
${ }^{29}$ SWM1_Int16
${ }^{30}$ SWM1_Int2
${ }^{31}$ ISGH_Int1
${ }^{32}$ SWM1_Int16
${ }^{33}$ SWM1_Int11
${ }^{34}$ MWM_Int3
${ }^{35}$ ISGH_Int1
${ }^{36}$ MWM_Int2
${ }^{37}$ MWM_Int 1
${ }^{38}$ MWM_Int4
${ }^{39}$ MWM_Int5
${ }^{40}$ SWM1_Int11
${ }^{41}$ ISGH_Int1
${ }^{42}$ SWM1_Int15 